\title{
Case report of African tick-bite fever from Poland
}

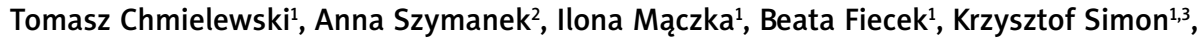 \\ Stanisława Tylewska-Wierzbanowska ${ }^{1}$
}

\author{
${ }^{1}$ Laboratory of Rickettsiae, Chlamydiae and Spirochetes, National Institute of Public Health - National Institute of Hygiene, Warsaw, \\ Poland \\ Head of Laboratory: Prof. Stanisława Tylewska-Wierzbanowska \\ ${ }^{2} 1^{\text {st }}$ Department of Infectious Diseases, Regional Specialist Hospital, Wroclaw, Poland \\ Head of Department: Prof. Krzysztof Simon MD, PhD \\ ${ }^{3}$ Division of Infectious Diseases and Hepatology, Wroclaw University of Medicine, Poland \\ Head of Division: Prof. Krzysztof Simon MD, PhD
}

Postep Derm Alergol 2013; XXX, 6: 396-398

DOI: $10.5114 / p d i a .2013 .39438$

\begin{abstract}
A confirmed case of rickettsiosis acquired in South Africa and recognized in Poland was described. The patient fulfilled clinical criteria highly suggestive of African tick bite fever, such as eschars, regional lymphadenitis, cutaneous rash within 10 days after his return from sub-Saharan Africa. Infection with Rickettsia africae was confirmed by polymerase chain reaction and sequencing.
\end{abstract}

Key words: Rickettsia africae, polymerase chain reaction sequencing, imported infection.

\section{Introduction}

African tick bite fever (ATBF) is caused by Rickettsia africae. The pathogen occurs as an endemic organism in sub-Saharan Africa and the eastern Caribbean. Cattle are the most important domestic reservoir, and the human is an accidental host [1]. Cattle ticks of the Amblyomma genus (mainly $A$. hebraeum and $A$. variegatum) are both reservoirs and vectors of this pathogen. Nearly $70 \%$ of $R$. africae infections are carried by $A$. hebraeum in endemic areas and indigenous cases occurring during agricultural work [2, 3]. However, there are cases of this disease among individuals who have returned from an African trip. Usually, the disease is mild and self-limited but some cases require hospitalization. African tick bite fever presents as an acute febrile disease with headache, myalgia, lymph node swelling, and maculopapular eruption with inoculation eschars.

In this study, we report a case of ATBF imported to Poland. A 45-year-old man without significant medical history was admitted to the $1^{\text {st }}$ Department of Infectious Diseases in Wroclaw (south Poland) with fever of $38^{\circ} \mathrm{C}$, muscle pain and weakness. Symptoms appeared about 5 days after his return from a 10-day safari in South Africa (near the Kruger National Park). The patient reported that after his return, he found several small ticks attached to the upper part of his thighs.
On admission to the hospital the patient was in fairly good condition, with body temperature of $37^{\circ} \mathrm{C}$. Physical examination revealed $0.5 \mathrm{~cm}$ ulcers and eschars at the sites of tick bites as well as disseminated macular and maculo-papular rash on the trunk and arms (Figures 1 and 2). In the left groin there was a tender, enlarged, $1.5-\mathrm{cm}$ lymph node. A rickettsial disease was considered.

\section{Case report}

Blood samples and scrapings from eschars were collected for serologic and polymerase chain reaction (PCR) tests. The IgM and IgG Rickettsia spp. level of serum antibodies, were detected with microimmunofluorescence test (Rickettsia IFA IgG, Focus diagnostic, USA). DNA from blood and skin samples was extracted with QIAamp Tissue Kit (Qiagen, Hilden, Germany). Bacterial DNA was examined by PCR for the presence of Rickettsia sp. citrate synthase gene ( $g l t A)$ method with RpCS.409d and RpCS.1258n primers, outer-membrane protein A (ompA) gene with primers Rr190-70 and Rr190-701 and 17 kDa outer membrane protein gene with primers pair Rr17.61p and Rr17.492n specific for SFG rickettsiae [4-6]. The QIAquick PCR purification kit (QIAGEN GmbH, Hilden, Germany) was used for the purification of PCR products to sequencing. All amplicons were sequenced with $A B I 377$

Address for correspondence: Ilona Mączka MSc, National Institute of Public Health - National Institute of Hygiene, 24 Chocimska St, 00-791 Warsaw, Poland, phone: +48 22542 12 61, e-mail: ilona.maczka@pzh.gov.pl Received: 6.02.2013, accepted: 23.05.2013. 


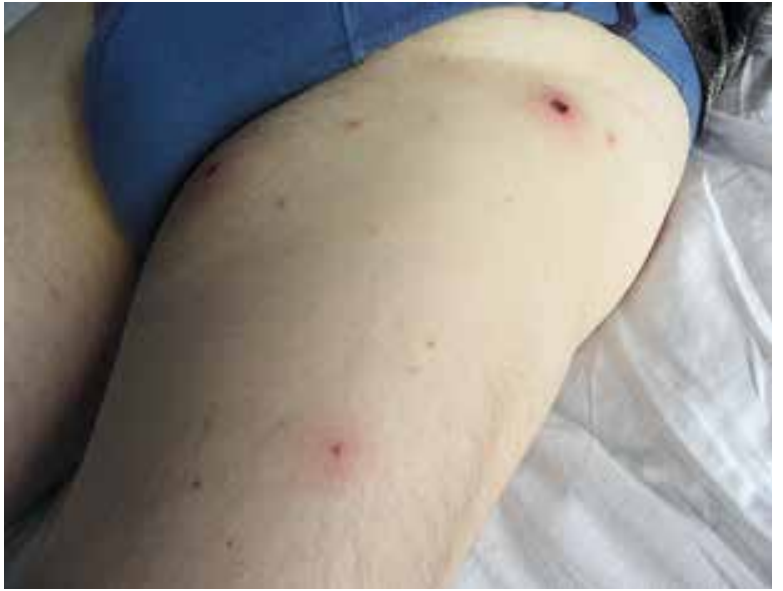

Figure 1. Cutaneous manifestations on the left upper leg: eschars and maculo-papular rash

DNA Analyzer (Applied Biosystems, USA) according to the manufacturer's recommendations. All sequences were edited using AutoAssembler software (Applied Biosystems, USA) and identified with the BLAST software and compared with sequences available in GenBank.

In laboratory findings, C-reactive protein (CRP) was elevated to $35 \mathrm{mg} / \mathrm{dl}$ and elevated liver enzyme levels (GPT - $57 \mathrm{IU} / \mathrm{I}, \mathrm{GOT}-57 \mathrm{IU} / \mathrm{l}, \mathrm{GGT}-69 \mathrm{IU} / \mathrm{l})$. Chest X-ray and abdominal ultrasound did not reveal any abnormalities. One week after onset of symptoms, IgG serum antibodies in titer of 256 and IgM antibodies in titer of 128 reacting with $R$. rickettsii antigen were detected.

DNA of Rickettsia sp. was found in PCR with primers specific to the citrate synthase ( $g l t A)$, outer membrane protein $\mathrm{A}$ (ompA) and the $17 \mathrm{kDa}$ protein genes in scrapings from eschars. Sequences of gltA gene fragment (605 nucleotide positions) revealed 99\% identity with R. africae strain ESF-5 and Rickettsia sp. CG13 strain sequences (GenBank accession no. CP001612.1 and HM538186.1). The sequence of amplicon (371 nucleotide positions) amplified with primers specific to $17 \mathrm{kDa}$ protein gene showed a 99\% similarity to the R. africae eSf-5 gene (GenBank accession no. CP001612.1).

The patient was given doxycycline $100 \mathrm{mg}$ twice a day for 14 days. The fever and muscle pain resolved after the first two doses of doxycycline, disseminated rash after 2 days of treatment and the eschars and ulcers healed within 2 weeks after initiation of therapy.

\section{Discussion}

A confirmed case of rickettsiosis acquired in South Africa has been recognized in Poland. The patient fulfilled clinical and epidemiological criteria highly suggestive of ATBF, such as multiple inoculation eschars, regional lymphadenitis, cutaneous rash within 10 days after his return from sub-Saharan Africa. Rickettsia africae infection was confirmed by PCR (detected sequences of genes

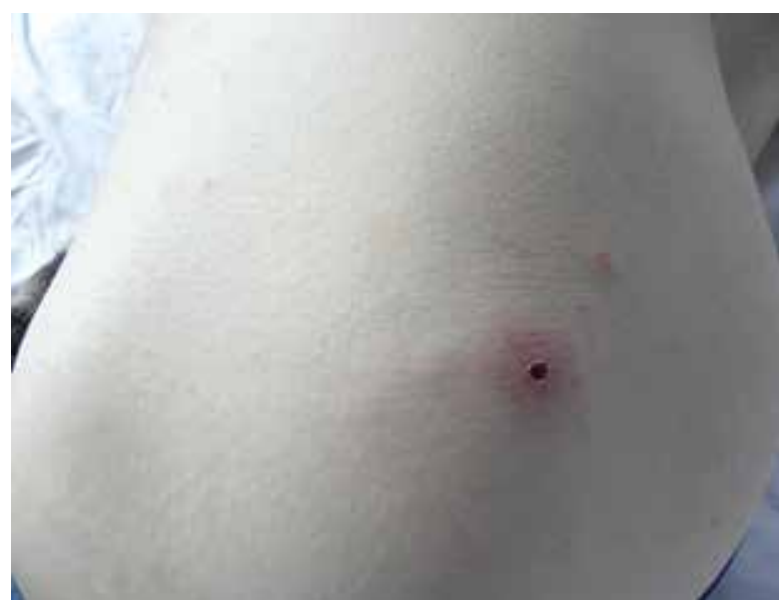

Figure 2. Eschar on the left upper leg

characteristic of $R$. africae strains) and serology (lgG titres $\geq 64$ and IgM titers $\geq 32$ to SFG Rickettsia antigens). In 2011, two indigenous SFG cases were recognized in Poland but with serology only $[7,8]$.

Rickettsia africae has been isolated or found by PCR in a number of African countries, including Niger, Mali, Burundi, Sudan [9], Chad, Ethiopia [10, 11], and in most countries of equatorial and Southern Africa [12] as well as in Senegal [13].

So far more than 350 travel-associated cases have been reported in Europe, North America, Australia, Argentina, and Japan. Most cases have been acquired in South Africa, where many popular wildlife attractions are organized in an area highly endemic for $R$. africae infections. African tick bite fever has been reported in a wide spectrum of travelers, including leisure safari tourists, business travels, foreign aid workers and soldiers [14]. Many reports have showed that rickettsial infections could account for $5.6 \%$ of all acute febrile infections developed in travelers returning from sub-Saharan Africa [13]. Until now, only a few cases however, have been reported in Central Europe $[15,16]$. In Poland this is the first case of ATBF but the numbers may increase with the development of business and tourism travel to sub-Saharan Africa.

Rickettsia africae was detected in the Slovak Republic in fleas collected from migratory birds returning from Africa. This is a new aspect in the epidemiology of this pathogen [17]. Many species of birds migrate from Africa into the Polish territory, and many of them nest near human settlements. Each year, for example, about 100 thousands of storks (Ciconia ciconia) fly to Poland after winter spent in Africa. The role of bird ectoparasites in the maintenance and dissemination of rickettsial infections is still unknown. Infection with $R$. africae may affect not only humans visiting Africa. 


\section{References}

1. Althaus F, Greub G, Raoult D, Genton B. African tick-bite fever: a new entity in the differential diagnosis of multiple eschars in travelers. Description of five cases imported from South Africa to Switzerland. Int J Infect Dis 2010; 14: 274-6.

2. Bartosik K, Bartosik K, Sitarz M, et al. Tick bites on humans in the agricultural and recreational areas in south-eastern Poland. Ann Agric Environ Med 2011; 18: 151-7.

3. Chmielewska-Badora J, Moniuszko A, Żukiewicz-Sobczak W, et al. Serological survey in persons occupationally exposed to tick-borne pathogens in cases of co-infections with Borrelia burgdorferi, Anaplasma phagocytophilum, Bartonella spp. and Babesia microti. Ann Agric Environ Med 2012; 19: 271-4.

4. Roux V, Rydkina E, Eremeeva M, Raoult D. Citrate synthase gene comparison, a new tool for phylogenetic analysis, and its application for the rickettsiae. Int J Syst Bacteriol 1997; 47: 252-61.

5. Roux V, Fournier PE, Raoult D. Differentiation of spotted fever group rickettsiae by sequecning and analysis of restriction fragment length polymorphism of PCR-amplified DNA of the gene encoding the protein rOmpA. J Clin Microbiol 1996; 34: 2058-65.

6. Webb L, Carl M, Malloy DC, et al. Detection of murine typhus infection in fleas by using the polymerase chain reaction. J Clin Microbiol 1990; 28: 530-4.

7. Chmielewski T, Rudzka D, Fiecek B, et al. Case of TIBOLA/ DEBONEL (tick-borne lymphadenopathy/ Dermacentor spp. - borne necrosis-erythema-lymphadenopathy) in Poland [Polish]. Przegl Epidemiol 2011; 65: 583-6.

8. Świtaj K, Chmielewski T, Borkowski P, et al. Spotted fever rickettsiosis caused by Rickettsia raoulti - case report. Przegl Epidemiol 2012; 66: 347-50.

9. Parola P, Inokuma H, Camicas JL, et al. Detection and identification of spotted fever group Rickettsiae and Ehrlichiae in African ticks. Emerg Infect Dis 2001; 7: 1014-7.

10. Mura A, Socolovschi C, Ginesta J, et al. Molecular detection of spotted fever group rickettsiae in ticks from Ethiopia and Chad. Trans R Soc Trop Med Hyg 2008; 102: 945-9.

11. Stephany D, Buffet P, Rolain JM, et al. Rickettsia africae infection in man after travel to Ethiopia. Emerg Infect Dis 2009; 15: 1867-9.

12. Cazorla C, Socolovschi C, Jensenius M, Parola P. Tick-borne diseases: tick-borne spotted fever rickettsioses in Africa. Infect Dis Clin North Am 2008; 22: 531-44.

13. Mediannikov O, Trape JF, Diatta G, et al. Rickettsia africae, Western Africa. Emerg Infect Dis 2010; 16: 571-3.

14. Jensenius M, Fournier PE, Didier Raoult D. Tick-borne rickettsioses in international Travellers. Int I Infect Dis 2004; 8: 139-46.

15. Hutterer J, Konrad K, Tappeiner G. South African tick bite fever. Hautarzt 1987; 38: 172-4.

16. Schuster J, Tantcheva-Poor I, Wickenhauser C, et al. African tick bite fever: papulovesicular exanthem with fever after staying in South Africa. J Dtsch Dermatol Ges 2008; 6: 379-81.

17. Sekeyová Z, Mediannikov O, Roux V, et al. Identification of Rickettsia africae and Wolbachia sp. in Ceratophyllus garei Fleas from Passerine Birds Migrated from Africa. Vector Borne Zoonotic Dis 2012; 12: 539-43. 